\title{
The Distribution of the Burden of US Health Care Financing
}

\author{
Patricia Ketsche ${ }^{1}$, E. Kathleen Adams ${ }^{2}$, Sally Wallace ${ }^{3}$, Viji Kannan ${ }^{4} \&$ Harini Kannan ${ }^{5}$ \\ ${ }^{1}$ Robinsons College of Business, Georgia State University, Atlana, Georgia, USA \\ ${ }^{2}$ Rollins School of Public Health, Emory University, Atlanta, Georgia, USA \\ ${ }^{3}$ Andrew Young School of Policy Studies, Georgia State University, Atlana, Georgia, USA, and African Tax \\ Institute, University of Pretoria, Pretoria, South Africa \\ ${ }^{4}$ Health Services Research and Policy, University of Rochester, Rochester, New York, USA \\ ${ }^{5}$ Jameel Poverty Action Lab (JPAL, South Asia), New Dehli, India \\ Correspondence: Patricia Ketsche, Robinson College of Business, PO Box 3988, Georgia State University, Atlanta, \\ GA, 30302-3988, USA. Tel: 404-413-7635. E-mail: pketsche@gsu.edu
}

Received: April 28, 2015

Accepted: May 18, 2015

Online Published: May 27, 2015

doi:10.5430/ijfr.v6n3p29

URL: http://dx.doi.org/10.5430/ijfr.v6n3p29

\begin{abstract}
The complex financing system that supports health care spending in the US makes estimation of the incidence of financing both daunting and important. A significant portion of financing is embedded in the tax system at all levels of government, while tax expenditures that subsidize private purchases implicitly transfer a large share of financing from private to public revenue sources. We compute and describe the final incidence of financing health care by major component and in total. We use the Kakwani measure of progressivity and find the overall incidence of US health care financing to be regressive although less so than in earlier years. This change is due in part to an increased federal role. We provide detail as to our methods and assumptions for benchmarking and assessment of the equity implications of financing health care in the future.
\end{abstract}

Keywords: incidence, health care, health insurance, public expenditures

\section{Introduction}

Health expenditures for the United States stood at 2.6 trillion dollars in 2010, an estimated 17.9 percent of GDP. Prior to national health care reform, these expenditures were expected to double by 2018 (Centers for Medicare \& Medicaid Services, 2010) and reach 25 percent of GDP by 2025 (Congressional Budget Office, 2010); current projections indicate spending will be almost $20 \%$ of GDP by 2020 (Keehan, et al., 2011). Although a large portion of funds flow into the system through employers and government, ultimately individuals and families bear the burden of all health care costs through taxes, reduced earnings on capital or labor, direct out-of-pocket payments, and premiums (Emanuel \& Fuchs, 2008). As the US prepares for changes in the financing of this sector of the economy, policy makers, analysts, and the general public will benefit from information on the incidence of the final burden of financing health care. One criterion for evaluating the financing system, and in particular the public component, is the vertical equity with which the financing of heath care expenditures is distributed across families. As health expenditure growth outpaces inflation and wage growth, understanding the pattern of its financing across income strata overall and by major component contributes to the ongoing policy debate.

Developing policies related to the projected growth in public health care expenditures also requires an awareness of the adequacy of revenue sources at each level of government and the taxing capacity of the federal compared to state governments. Some public health care programs, such as Medicaid, are funded by progressively distributed federal revenue and also by fifty different state tax systems which exhibit varying degrees of regressivity. State financed spending may therefore offset or augment the progressivity of health care financing inherent in federal funding. Federal-state-local funding of health care thereby raises a number of important fiscal federalism issues that will likely intensify under health reform as it further expands and complicates state and federal cost sharing arrangements, especially given the increased options states now have. 


\subsection{Literature Review}

The most recent study examining the equity of health care financing in the US uses 1987 data, revealing a considerable gap in the literature (Wagstaff, et al., 1999). Most work on equity in health care financing compares the US to other industrialized countries and has led to the conclusion that the burden of financing in the US is distributed in a regressive manner (Cantor, 1988; Gottschalk, Wolfe, \& Haveman, 1989; Wagstaff \& Doorslaer, 1992; Wagstaff, et al., 1999). Other studies have analyzed the incidence of the benefit of public spending, but not private spending, on health care (Selden \& Sing, 2008) or have analyzed only parts of the incidence of financing health care, such as Medicare (Bhattacharya \& Lakdawalla, 2006; McClellan \& Skinner, 2006; Skinner \& Zhou, 2004) or employer coverage (Jensen \& Morrisey, 2001; Olson, 2002; Selden \& Bernard, 2004). These earlier analyses were prior to the decline in private spending associated with public expansions since the early 1990s, especially expansion of state coverage. This study provides an update to these previous studies.

The expanding role of the states in financing the health care system creates an additional incentive for understanding the level of vertical equity within the whole system. States are far less likely than the federal government to have vertical equity or redistribution as an explicit goal of their tax systems, notwithstanding the redistributive motive behind their health care related spending. However, states vary substantially in their propensity to choose progressive versus regressive fiscal instruments (Bahl, Martinez-Vazquez, \& Wallace, 2002) and yet, due to income tax deductibility, state and federal choices are inextricably linked. If our health care system is to meet equity goals inherent in the programmatic spending, we need a clear understanding of the trade-offs between federal and state/local public financing and between public and private financing. Therefore, our estimates of the overall equity of the financing system incorporate both public and private financing.

In this study, we describe a family's contribution to health care financing as a percent of total family income by income quintile. The numerator, the family's contribution to health care financing, includes out-of-pocket payments; premiums paid for public and private insurance net of the tax subsidy for employer sponsored coverage; taxes paid to support federal, state, and local general fund revenues; revenues earmarked for health care (e.g. federal payroll tax for Medicare); and the tax expenditures associated with the subsidy for private coverage. The denominator is total family income. In prior work we have provided the definition and derivation of each component of this ratio and used the ratio by income quintile to discuss the progressivity of the US financing system (Ketsche, Adams, Wallace, Kannan, \& Kannan, 2011). In this paper we use the data to estimate a Kakwani progressivity index; the value of this index is that we can separate out the effects of the mix of taxes from the incidence of each tax on overall progressivity. It also allows us to compare progressivity in the US to other countries and over time. In addition to updating the existing literature, we expand on previous studies by examining both public and private financing of health care expenditures at the federal, state and local levels. Our estimates of the incidence of the financing of the system along with the explication of our methods provide a basis for assessing the evolution of the equity of the US financing system under the Affordable Care Act (ACA).

We find that the financing of the public portion of health care spending is, in the aggregate, progressive but only because of the dominance of federal spending. The mix of state versus federal spending is key to the overall equity of the US financing system. Financing of the private sector is, not surprisingly, regressively distributed. Despite public programs designed to limit high out-of-pocket spending for low-income populations, the bottom quintile of the population continues to bear a disproportionate burden of financing the system, especially with respect to out-of-pocket spending. Moreover, we find that the relative burden borne by low- versus high income families differs by state. The US system remains regressively financed even when public and private financing are considered together. However, our approach is not without controversy and raises important questions about financing versus benefit as well as financing of health care over a lifetime.

\subsection{Financing versus Benefits}

Prior analyses, as well as ours, proceed from a consensus that the public financing of health care should consider some degree of "ability to pay" or vertical equity. In countries with public delivery systems or insurance programs from which all citizens are entitled to receive care this is less controversial than in the US, where some individuals are entitled to consume direct benefits from the public system while others are not entitled to receive care from the system they fund through taxes. Incorporating private spending into such equity measures is even more complex because of the relationship between private spending and private consumption choices. Thus, some would argue that a complete analysis requires a 'flow of funds' approach that considers both the financing and the spending on services together. Such is the approach, for example, of Smith and Normand (2009) in their analysis of the equity of the Irish system. 
However, public or private direct spending for patient services in a given year is a weak proxy for the distribution of the benefits of the health care system. Most obviously, both public and private insurance programs provide risk reduction for all participants. Therefore, assessing the distribution of the benefits based on spending for individuals' consumption ignores the risk reduction that is distributed partially independent of actual consumption. A significant portion of public spending supports the explicit provision of public goods, for example payments to hospitals through the Disproportionate Share (DSH) programs in Medicaid and Medicare, or enhanced reimbursement to critical access hospitals. Implicitly, spending for individually consumed services supports the maintenance of a health system infrastructure that is ultimately available for all in the community. More broadly, investments in maternal and child health improve productivity of the future labor force, while financing for long-term care benefits family caretakers who are freed up to participate in the labor market. Therefore, the benefits of both public and private spending flow well beyond the consumers of health services in a given year or even the enrollees in the system to the general public. Even if we could disentangle public from private benefits of spending, dollars are a poor proxy of the private benefits given variations in prices paid for the same services, variations in quality that are not necessarily reflected in prices, and non-pecuniary variations in price (e.g. waiting times, stigma, travel costs) across providers and payer types.

Thus, the focus of this paper is on a partial equilibrium model of the family burden of financing for health care services. We do not estimate the incidence of the benefit of health care consumption. Such analysis is beyond the scope of this research and provides fertile ground for future analysis. We refer the reader to examples of such distributional analysis of public spending (Selden \& Sing, 2008) or Medicare (McClellan \& Skinner, 2006).

\subsection{Point-In-Time versus Life Cycle Estimates}

Because significant health related events occur at unpredictable intervals in a lifetime, spending for care consumed is often concentrated in limited episodes over the course of an individual's life. This 'lumpy' distribution of health care spending leads some researchers to approach an analysis of health care financing using a life-cycle framework. This approach is particularly useful to describe how income influences a family's spending choices (i.e. consumption) across a life-cycle, and how the potential to invest in health in one stage of life can reduce spending in a different phase (Ozkan, 2011). This approach would be particularly relevant to analysis of out-of-pocket spending in the private sector.

Since the public funding of health care is a function of earmarked and general fund revenues, there is the potential to overstate the tax burden on families that occur early in their earning years relative to a lifecycle incidence approach which would typically smooth out the tax burden. Kotlikoff and Summers(1979) pioneered one of the early theoretical analyses of the incidence of taxes using a life-cycle model and demonstrated the potential differences in the distributional burden of taxation using this approach. These differences are a function of individual behaviors (human capital accumulation and retirement decisions for example) which interact with macroeconomic effects such as economic growth. With respect to public financing, a life-cycle approach might emphasize that Medicare is a social insurance program wherein payments today purchase a future benefit and tax support for Medicaid ensures its availability in the face of unexpected and future (long-term care) need. However, promised future benefits are always subject to the political environment and can, with sufficient legislative support, be changed at any time. Therefore, we believe financing through the public sector and through premiums should rightly be considered point-in-time payments rather than prepayments for future benefits.

We present a point-in-time approach for a given cohort of families in 2004. While the age and income distribution of future cohorts will change, and events such as the current recession may alter the relationship of age and income in future cohorts, we cannot address these complexities in our point-in-time approach. However, our cross sectional, point-in-time approach should yield complementary results to such analysis and could provide a benchmark for analyzing such changes.

\section{Method}

We use the Annual Social and Economic Supplement to the Current Population Survey (CPS) from March 2005 and 2006 to estimate a model that reflects income and health care spending for 2004. For additional methodological details and a delineation of our assumptions, see the online appendix from our related work (Ketsche, et al., 2011). We use these data, which are representative of the non-institutionalized population in the US and by state, to build a family based model. We develop a comprehensive income measure inclusive of all wages and salaries and other forms of cash income, major transfer income, imputed rent for homeowners, pre-tax employer contributions for public and private retirement and for health insurance, values of Medicaid and Medicare and indirect business taxes. 
We compare aggregated spending totals to income to generate the shares of income paid through private and public financing and then present Kakwani indices to describe the degree of progressivity inherent in the system.

Measures of the family's share of publicly financed health care spending are developed in a 'top down' approach by, first, collecting total spending and total revenues generated from each tax source, then calculating each family's share of the tax base or liability, by type of tax (as explained below). In contrast, we developed measures of the shares of privately financed health care spending from the 'bottom up'. Out-of-pocket expenses are derived from models developed using the Medical Expenditure and Panel Survey (MEPS). We impute to families premiums for public and private insurance adjusted for those characteristics that affect premium cost and the duration of coverage.

\subsection{Measuring Family Income}

The accounting period we use is annual and, as with the rest of the data in our analysis, income values are collected for the year 2004. We present burden measures by income quintile and hence, its definition is critical to the integrity of our results. Most analysts argue that income is broadly defined as regular, irregular, cash, and non-cash items that enable a family to consume more goods and services today (Smeeding \& Weinberg, 2001). (Note 1) Our measure reproduces the basic components of comprehensive income described by the Canberra Group, integrated with the Congressional Budget Office (CBO) and the Urban Institute-Brookings Tax Policy Center (TPC) measures by including corporate income tax liability as part of income. Our income measure comprises all sources of cash income (both taxed and tax exempt), non-cash income, taxes and benefits paid by employers, and imputed rental value of owner occupied housing. (Note 2)

Because CPS top codes many of the variables we use to determine income, we make an adjustment using data from the National Bureau of Economic Research (NBER). NBER provides a publicly available, online tax simulation program, TAXSIM, which we use to estimate the adjusted gross income (AGI) and income tax liability for each CPS family and then benchmark the income by unit in our data against national data published by TPC and the Tax Foundation. We adjust the data through reweighting the top income families $\left(99^{\text {th }}\right.$ percentile) in the CPS data until the federal income tax liability calculated in TAXSIM for the top one percent aligns with that reported by the Tax Foundation for 2004. (Note 3)

We use the family as the unit of analysis in recognition that income and consumption decisions are often shared by family members. As an income-sharing unit, families are large enough to capture all sources of regular income, as well as reflect the potential for economies of scale. (Note 4) Moreover, families rather than individuals form the taxing units in our system and over half of all health care expenditures are financed through the public sector. We stratify families by income quintile using the above comprehensive income measure with an equivalence scale adjustment. (Note 5)

\subsection{Health Care Expenditures}

Documentation of health care expenditures by the Centers for Medicare \& Medicaid Services' (CMS) is published in the National Health Expenditure Accounts (NHEA) (Centers for Medicare \& Medicaid Services). We used the NHEA 2004 health services and supplies expenditure values as our "control total" of national expenditures on health care, but collected data from multiple sources in order to satisfy the level of granularity called for in our model. For example, while the NHEA provides total state and locally funded health expenditures, this national total is not itemized by state; we need state specific spending in order to allocate the burden of each state's tax structure. Further, our ability to disaggregate program expenditures (e.g. Medicare) by revenue source (e.g. payroll taxes or premiums) or component (e.g. hospital insurance [Part A] or supplementary medical insurance [Part B]) is limited within the NHEA. The NHEA estimates for total private expenditures also lack sufficient detail. We therefore compile public and private sector health care expenditures from various data sources [see Appendix 1]. Within the public sector we include expenditures financed from 'own' tax revenues at federal, state, and local level governments and for the private sector, out-of-pocket payments and premiums.

\subsection{Public Sector Revenues and Incidence}

After excluding earmarked tax revenue sources, we assume that each tax funds health care expenditures proportional to its contribution to general revenue consistent with US Census Bureau, Census of Governments reports. (Note 6) As shown in Table 1, income taxes dominate at the federal level while general and selective sales dominate at the state level; taxes that comprise less than 5 percent of the total at the state level are lumped into an 'other' tax category. The most important local tax is the property tax, though local governments also impose general and selective sales taxes and individual income taxes. (Note 7) 
Table 1. Composition of general fund at each government level, 2004

\begin{tabular}{lc}
\hline Federal Government & \\
Individual Income Tax & $72.6 \%$ \\
Corporate Income Tax & $17.0 \%$ \\
Excise Taxes & $3.3 \%$ \\
Estate \& Gift Taxes & $2.2 \%$ \\
Customs \& Duties & $1.9 \%$ \\
Federal Reserve \& Other Taxes & $2.9 \%$ \\
State Government (average of 50 states and DC) & \\
General Sales Tax & $33.5 \%$ \\
Excise Taxes & $12.6 \%$ \\
Individual Income Tax & $31.8 \%$ \\
Corporate Income Tax & $5.2 \%$ \\
License Fees & $8.1 \%$ \\
Property Tax & $2.7 \%$ \\
Severance (Coal \& Oil) Tax & $3.2 \%$ \\
Other Taxes & $3.0 \%$ \\
Local Government (average of 50 within state averages and DC) \\
Property Tax & $64.0 \%$ \\
General Sales Tax & $16.3 \%$ \\
Selective Sales Tax & $6.2 \%$ \\
Individual Income Tax & $4.7 \%$ \\
Corporate Income Tax & $0.2 \%$ \\
License & $0.8 \%$ \\
Other & $7.8 \%$ \\
\hline
\end{tabular}

To distribute the burden of tax funded healthcare spending, we rely on existing analysis of tax incidence. Appendix 2 describes in detail the research that supports our incidence assumptions and we provide a brief summary below.

We follow the wide spread consensus that the incidence of individual income tax falls entirely on labor. Although the statutory incidence of payroll tax in the US is equally borne by employees and employers, there is also a general consensus that employees bear the full economic burden of this tax through lower wages. The economic burden of sales and excise taxes are assumed to fall on consumers of the taxed good, consistent with findings by Poterba (1996) that state and local taxes are fully shifted to consumers in the form of higher prices, and Besley and Rosen (1999) who conclude that prices shift at least by as much as the tax.

There is somewhat less consensus with respect to the corporate income tax. Since corporations are allowed to deduct interest paid on debt to derive taxable income, the corporate tax is generally viewed as a tax on returns to equity capital. (Note 8) In a standard general equilibrium framework (Harberger, 1962), the incidence of the tax may ultimately fall on capital and/or labor and we therefore present results assuming that labor and capital bear the burden of the corporate tax equally. We allow for the possibility of shifting to foreign owned capital and assume that 11.5 percent (Note 9) of the capital burden of corporate tax is exported outside the US economy.

The economic burden of property taxes is assumed to fall on capital and consumers of housing services with some debate about relative shares. (Note 10) We combine differing theoretical approaches and assume the burden of the property tax is shared equally between capital and consumers of housing (owners and renters). Severance taxes on oil, gas and coal are used only in a small number of states. (Note 11) Severance tax on oil/gas is assumed to be borne by owners of capital and the severance tax on coal is assumed to be borne by all consumers nationally based on the dominance of a few states in this market and lack of international competition. (Note 12) Finally, we assume that the 
economic burden of the estate tax is borne by the descendants, an assumption adopted by many incidence studies (Cronin, 1999; Feenberg, Mitrusi, \& Poterba, 1997).

\subsection{Private Sector Spending}

The burden of out-of-pocket spending is clear, but the link between employment and health insurance makes estimating the incidence of premiums complex. Economic theory suggests that employers are indifferent between wages and fringe benefits and will offer the combination that attracts or retains the optimal workforce. This implies that employees bear the cost of insurance through reduced wages, at least in the long run. However, the positive correlation between total compensation and preference for health insurance has long made empirical identification difficult (Leibowitz, 1983). Thus, the relationship between employment and health insurance in general and wages and health insurance in particular, has been the subject of extensive research (Gruber, 2000; Pauly, 1997). Several studies have identified compensating differentials, consistent with theory, that indicate at least in the aggregate and long run, health insurance substitutes for wages and the incidence is on workers (Miller, 2004; Morlock, 2000; Olson, 2002; Scheiner, 1999)

Thus, to the extent that risk pooling is complete, wages should adjust for average premiums. However, if risk pooling within the employment based system is incomplete, then estimating incidence based on average premiums could incorrectly assign the costs across workers. Thus, it may be that wage offsets in the presence of health risks (pregnancy, obesity) that affect consumption or expected consumption, are different than wage offsets for healthy populations (Bhattacharya \& Bundorf, 2009; Gruber, 1994). Alternatively, if wages are 'sticky' and cannot fully adjust for premium increases in the short run, it may be that firms respond through a work force reduction, which would imply premium incidence is spread more broadly in the population (Sommers, 2005). These latter possibilities are beyond the scope of this project but provide fertile ground for analysis in future work. We assume premiums fall fully on workers' wages.

\subsection{Measurement}

\subsubsection{Public Incidence Measurement}

We allocate the burden to each family using the data on public sector health program expenditures and the proportion each tax type constitutes of the general fund revenue (GFR) used to pay for those expenditures. The dollar amount of the GFR is first calculated as noted earlier [see Table 1]. We then apply the proportion of the general fund revenue $(\$ \mathrm{GFR})$ funded by the $\mathrm{i}^{\text {th }}$ tax $\left(\$ \mathrm{Tax}_{\mathrm{i}}\right)$ to the $\mathrm{j}^{\text {th }}$ health care program $(\$ \operatorname{Program} \mathrm{j})$, in order to calculate the variable "Program ${ }_{\mathrm{j}}$ Tax $_{\mathrm{i}}$ " which is the 'tax-financed' health care spending for each program, by each tax type:

$$
\text { Program }_{\mathrm{j}} \text { Tax }_{\mathrm{i}}=\left[\frac{\$ \text { Tax }_{i}}{\$ G F R}\right] \times\left[\$ \text { Program }_{j}\right]
$$

For example, given that the Individual Income Tax constitutes 73 percent of all federal general fund revenues, we allocate 73 percent of spending for each federally financed health care program to this tax source; this includes Medicare Part B, a small portion of Medicare Part A, (Note 13) the federal share of Medicaid and Children's Health Insurance Program (CHIP), and 'other' federal health care programs not financed by earmarked revenues.

To derive the amount each family pays for each publicly funded program by tax type we calculate their share of tax based on their share of the tax base (largely wages, income or consumption) which bears the economic incidence (see Appendix 3). We multiply total health care spending by program and tax type by the family's share of that tax type to determine the amount each family pays for each publicly funded program through each tax type.

We calculate a family's share of a particular tax, using the family's value for that tax's base and dividing it by the tax base summed over all families. Generally, for federal taxes, the base is summed over all families in the nation and for state taxes, over all families in the state. The base for taxes on capital is always summed nationally (versus within a state) to reflect the mobility of capital. The dollar value of the family's tax base is found in the CPS data with two exceptions: (1) federal and state income tax liability for each CPS family is derived from the NBER TAXSIM; (2) dollars spent on consumption are predicted using the Consumer Expenditure Survey (CES). These expenditure estimates serve as a base for license fees and sales, excise, coal severance, and property taxes.

When taxes have multiple bases, such as corporate income taxes, a family's share of wages (wages and salary, self-employment income, and farm income) is applied to a portion of that tax's generated revenue (one half in the case of the corporate tax), while the family's share of capital (interest, dividends, net capital gains, and rent income) is applied to the other portion. Before the latter half is distributed we reduce it by 11.5 percent, based on IRS data, to account for international capital mobility. 
Allocating sales taxes to individual families is particularly intricate. Sales tax revenue is divided into two main categories: sales taxes derived from (1) business to business sales and (2) business to consumer sales (Ring, 1999). The first category is further divided into (a) international business sales (11.5 percent of total), (b) sales within state (estimated by personal income divided by gross state product) and (c) sales to other states in the US (estimated as (1-personal income/gross state product). The sales tax revenue generated from business to business (US) sales but exported to other states is allocated to families based on their share of total consumption at the national level; sales taxes generated by business to business and remaining in the state, are allocated based on families' shares of total consumption within their state. The sales tax revenue generated from direct consumer sales remaining within a state is allocated to families based on their share of their state sales taxes while the direct consumer sales tax exported to other states via tourism is allocated to families based on their share of national personal income. The direct consumer sales tax revenue falling on international tourists in the state (estimated by applying average state tax rate to expenditures by international tourists by state) is separately estimated. The share of sales taxes paid via international consumers and businesses represents a burden to individuals outside of the U.S and is not included in our model. Appendix 3 provides detail on all steps taken to allocate tax burdens.

\subsubsection{Private Spending Measurement: Out-of-Pocket}

Out-of-pocket (OOP) spending is estimated using a two part model (Deb, Manning, \& Norton, 2008) to, first, estimate the probability of any expenditures and, second, estimate the level of expenditures conditional on any expenditure greater than zero. The expected individual expenditures were generated using the relationship:

$$
\text { Expected OOP }=\{\text { Prob }(0 O P>0) *(\operatorname{Exp}(0 O P) \mid O O P>0\} .
$$

The model bridges the MEPS-HC and CPS data sets and controls for demographics (age, race/ethnicity, marital status, education), income, work status, location (state and urban/rural status), coverage type, and health status (Note 14). Individual expected expenditures are summed to the family level and account for over $\$ 188$ billion in health care spending. We note that our overall approach prevents us from identifying outliers in out-of-pocket expenditures which, in turn, prevents us from generating estimates of the tax expenditure (through deductions) associated with very high out-of-pocket spending. (Note 15)

Because of the large out-of-pocket spending associated with the institutionalized population, (Note 16) we supplement our model with out-of-sample estimates of the distribution of out-of-pocket spending associated with the institutionalized population. We use the Medicare Current Beneficiary Survey (MCBS) to estimate that Medicare recipients with institutional stays of greater than 100 days paid a total of $\$ 32.7$ billion in 2004 out-of-pocket for all health care services. This compares with NHEA estimates of approximately $\$ 31$ billion in out-of-pocket payments just for nursing home care in the same year. Although the institutionalized populations are not represented in our sample, we match institutionalized populations to the respective quintiles based on cash income. We then allocate the spending of the institutionalized to the appropriate income strata proportional to the share of elderly (over 65) in the family adjusting for health and marital status of elderly family members. Thus, we allocate the out-of-pocket spending of the institutionalized to representative families within our sampling frame.

\subsubsection{Private Spending Measurement: Premiums}

Our fundamental incidence assumption regarding employer sponsored coverage is that the full premium unadjusted for age, sex, and health status is incident on worker wages. Appendix 1 presents the data sources used to obtain average total premiums for private, state, and federal employees as well as retirees. These data are used to assign a premium amount and an employer contribution dollar value to those who report in the CPS that they hold a group policy. A limitation in this process is that differences in plan generosity such as those identified by Royalty and Solomon (1999) are not observable. We use the CPS based estimates of employer contribution for health insurance as a control to adjust our matched premium and employer payments by wages. In addition to the employer contribution for coverage, the portion of the employee contribution sheltered from taxation through a Section 125 (cafeteria) plan is estimated based on firm size (Quincy, 2008).

We then generate an estimate of the tax liability for each family with and without the tax preferred portion of the group health premium added to wages (active worker coverage) or other income (self-employed and retirees) using TAXSIM. This permits an estimate of the tax subsidy identified separately for federal and state income tax and for payroll taxes. We adjust gross premiums for this subsidy and the incidence of the tax expenditures are then shifted back to the public sector general revenue for income tax based subsidy and payroll tax systems.

We also impute premiums for individually purchased private coverage and Medigap supplemental coverage using the data sources identified in Appendix 1. Two public programs obtain premiums from recipients, Medicare Part B 
and CHIP. We impute 90 percent of the statutory premium for public coverage in Medicare Part B to all individuals reporting enrollment in Medicare and family income that is above the level for Medicaid-funded premiums. (Note 17) For families reporting children enrolled in CHIP, we impute premiums based on the states' reported premium level.

\subsection{Vertical Equity Analysis}

We stratify families by income quintile using our equivalence scale adjusted income measure to present burdens by quintile and by spending type. We also derive a summary measure of vertical equity using the Kakwani progressivity index. The Kakwani compares the distributional equality of the concentration curve for each payment source to the Gini coefficient which measures the equality of the underlying distribution of income. It allows us to compare progressivity overall and across payment sources (e.g. federal versus state, public versus private), to prior estimates of the progressivity of the US system (Wagstaff, et al., 1999). It also allows for comparisons between states and to compare the net incidence pre- and post-tax expenditures for health insurance.

\section{Results}

\subsection{Incidence by Income Quintile}

Table 2 expands upon the descriptive work in our related publication (Ketsche, et al., 2011) and presents the mean income measures for each of the five income quintiles as well as the percent of income contained within each quintile. Families in the lowest quintile receive only 3 percent of income, while over half of all income is concentrated among families in the top quintile. Income concentration within the highest quintile is notable, with average income among the top 5 percent of families almost three times that of all other families within that quintile.

Table 2. Income distribution \& health care payments as a percent of income

\begin{tabular}{|c|c|c|c|c|c|c|c|c|}
\hline & \multirow{2}{*}{$\begin{array}{c}\text { All } \\
\text { Families }\end{array}$} & \multicolumn{5}{|c|}{ By Quintile } & \multicolumn{2}{|c|}{ Highest Quintile } \\
\hline & & Lowest & 2nd & 3rd & 4th & Highest & $\begin{array}{c}\text { bottom } \\
15 \% \\
\end{array}$ & top 5\% \\
\hline Mean Income & 78,038 & 13,450 & 34,712 & 56,439 & 87,908 & 197,684 & 143,156 & 361,268 \\
\hline \multicolumn{2}{|c|}{ Percent of Total Income } & $3 \%$ & $9 \%$ & $14 \%$ & $23 \%$ & $51 \%$ & $28 \%$ & $23 \%$ \\
\hline \multicolumn{9}{|c|}{ Health Care Payments as a percent of Income } \\
\hline Federal & $6.8 \%$ & $3.1 \%$ & $3.3 \%$ & $4.0 \%$ & $5.3 \%$ & $9.1 \%$ & $7.1 \%$ & $11.4 \%$ \\
\hline State & $2.0 \%$ & $3.0 \%$ & $2.0 \%$ & $1.8 \%$ & $2.0 \%$ & $2.0 \%$ & $2.1 \%$ & $2.0 \%$ \\
\hline Local & $0.1 \%$ & $0.3 \%$ & $0.2 \%$ & $0.1 \%$ & $0.1 \%$ & $0.1 \%$ & $0.1 \%$ & $0.1 \%$ \\
\hline Total Public & $8.9 \%$ & $6.4 \%$ & $5.5 \%$ & $6.0 \%$ & $7.4 \%$ & $11.2 \%$ & $9.2 \%$ & $13.6 \%$ \\
\hline Premiums & $4.4 \%$ & $6.0 \%$ & $5.7 \%$ & $5.9 \%$ & $5.4 \%$ & $3.2 \%$ & $4.4 \%$ & $1.7 \%$ \\
\hline Out-of-Pocket & $2.2 \%$ & $10.2 \%$ & $4.8 \%$ & $3.3 \%$ & $2.0 \%$ & $0.9 \%$ & $1.2 \%$ & $0.5 \%$ \\
\hline Total Private & $6.6 \%$ & $16.3 \%$ & $10.5 \%$ & $9.2 \%$ & $7.4 \%$ & $4.1 \%$ & $5.6 \%$ & $2.2 \%$ \\
\hline $\begin{array}{l}\text { Total Health } \\
\text { Care Spending }\end{array}$ & $15.5 \%$ & $22.7 \%$ & $16.0 \%$ & $15.1 \%$ & $14.8 \%$ & $15.3 \%$ & $14.8 \%$ & $15.8 \%$ \\
\hline
\end{tabular}

Table 2 reflects the incidence of the taxes used to support heath care spending at the federal, state, and local levels, including the tax expenditure for private group insurance. Overall, spending on federally funded health care programs imposes the heaviest burden on families, equal to almost 7 percent of family income. Spending supported through state tax revenues equals 2 percent while that supported by local tax revenue streams represents only 0.1 percent of total family income. In total, publicly funding heath care spending absorbs an estimated 9 percent of income on average. 
The incidence of these publicly funded health care expenditures across quintiles of family income are largely in line with expectations given the incidence of the specific taxes used at the federal, state and local governmental levels. For example, the incidence using federal tax sources is progressive throughout the income distribution increasing from around 3 to 9 percent in the highest income quintile reflecting the dominance of the federal individual income tax. We also find the Medicare portion of the payroll tax to have a slightly progressive pattern (Note 18) so these, as well as the corporate income tax and in particular taxes on estates/gifts, add to the progressive pattern at the federal level. The progressivity of these general fund revenues are seen in the yet higher percentage of income paid for federally funded health care by families in the very top of the income distribution ( $>11$ percent).

In contrast, the pattern for state taxes is mildly regressive, moving from 3 percent of income for families in the lowest income quintile to 2 percent for families in the highest income quintile. The incidence of local taxes used to finance health care services is also regressive but very small in magnitude. This state/local tax incidence pattern reflects the importance of regressive general and selective sales taxes at the state level and the use of (also regressive) property taxes as well as sales taxes at the local level.

Total public spending for health care is generally progressively financed, consuming over 6 percent of low-income families' comprehensive income and over 13 percent of income among families in the top 5 percent of earners. Hence, despite the regressive nature of state and local public spending, the levels of federal spending dominate total public expenditures and result in an overall progressively financed public sector although the pattern is not progressive throughout as families in the lowest quintile pay slightly more than those in the second quintile.

Not surprisingly, private sector spending on health care represents a significantly larger burden for low- versus higher income families. Families in the lowest income quintile expend over 10 percent of income for out-of-pocket expenditures on health care. This results in part from the lower likelihood that these families have health insurance coverage and from the likelihood that elderly adults in this income range will spend high levels if institutionalized. On the other hand, out-of-pocket spending among families in the top quintile represents less than one percent of income. Premiums are also regressively distributed, consuming 6 percent of total income among the lowest income quintile families despite the low likelihood of having group coverage among these families. Total private spending consumes over 16 percent of income among families at the lowest end of the income spectrum, while consuming only 4 percent of income among families in the top quintile.

Total health care spending is estimated in our model to consume about 15.5 percent of income. Despite the relative progressivity of the federally funded components of the system, the system of health care financing is regressive overall, consuming almost 23 percent of income among families in the lowest quintile and 15 percent among families in the highest quintile.

\subsection{Kakwani Progressivity Indices}

The data provided in Table 2 provides granular detail about spending by source and for each income quintile. In particular, we note that in some cases shares of funding are not monotonically related to income, as shares are at the lowest level among middle income families. Since it is difficult to assess the system in a comprehensive manner or compare across funding sources without a single index of progressivity, we present Kakwani indices for each funding source and the respective shares of total revenue derived from each source in Table 3.

We find the overall incidence of financing health care to be slightly regressive $(-0.01)$. The public sector is progressively financed $(0.15)$ because of the dominance of federal spending $(0.20)$ over state spending that is, overall, barely regressive (-.003). While both premiums (-0.12) and out-of-pocket spending $(-0.40)$ represent a significantly larger burden for low income populations, together they comprise less than half of all spending (42 percent), so that on net, the financing system is, as noted, slightly regressive.

We use a more restrictive income definition of income to generate another set of Kakwani indices for comparison with earlier estimates (Wagstaff, et al., 1999) that use cash income adjusted by the equivalence scale. (Note 19) We find that financing of health care in the US, measured relative to the distribution of cash income, is more regressive than when measured against broad income. As shown in Table 3, the overall Kakwani changes from -0.01 to -0.06 when using cash income. This is consistent with the fact that lower income families obtain a greater share of income from the non-cash sources included in our broad income measure. Wagstaff et al. reports that the overall incidence of the US system in 1987 was regressive (-0.13) reflecting the combination of progressive public sector funding sources $(0.11)$ combined with a highly regressive private sector $(-0.32)$ and especially out-of-pocket payments $(-0.39)$. Thus, our estimates indicate that the US financing system has become less regressive over the past 2 decades. 
Table 3. Progressivity of health care financing

\begin{tabular}{|c|c|c|c|c|c|c|c|c|}
\hline \multirow{3}{*}{\multicolumn{2}{|c|}{ Coefficient }} & \multicolumn{7}{|c|}{ Kakwani Measure of Progressivity for Health Care Spending From: } \\
\hline & & \multirow[b]{2}{*}{ Federal } & \multirow{2}{*}{$\begin{array}{l}\text { State/ } \\
\text { Local }\end{array}$} & \multirow{2}{*}{$\begin{array}{c}\text { Total } \\
\text { Public }\end{array}$} & \multirow[b]{2}{*}{ Premiums } & \multirow[b]{2}{*}{ OOP } & \multirow{2}{*}{$\begin{array}{c}\text { Total } \\
\text { Private }\end{array}$} & \multirow{2}{*}{$\begin{array}{c}\text { All } \\
\text { Sources }\end{array}$} \\
\hline & & & & & & & & \\
\hline Shares of Tota & ling & $44 \%$ & $14 \%$ & $58 \%$ & $28 \%$ & $14 \%$ & $42 \%$ & \\
\hline \multicolumn{9}{|c|}{ Income Specification: } \\
\hline \multicolumn{9}{|c|}{ Equivalized } \\
\hline \multicolumn{9}{|c|}{ Comprehensive } \\
\hline Income & 0.45 & 0.20 & -0.003 & 0.15 & -0.12 & -0.40 & -0.21 & -0.01 \\
\hline \multicolumn{9}{|l|}{ Equivalized } \\
\hline Cash Income & 0.50 & 0.15 & -0.05 & 0.11 & -0.19 & -0.47 & -0.28 & -0.06 \\
\hline \multicolumn{9}{|c|}{ Wagstaff et al (1987) } \\
\hline Shares of spen & 987) & & & $49 \%$ & $29 \%$ & $22 \%$ & $51 \%$ & \\
\hline Equivalized Ca & ome & & & 0.11 & -0.24 & -0.39 & -0.32 & -0.13 \\
\hline
\end{tabular}

When we compare our component indices, we see that despite alternative assumptions regarding the incidence of specific taxes, our estimates are generally consistent with that found in the prior study. The incidence patterns within the 2004 US private sector financing system are similar to those seen in the 1987 data but include somewhat less regressive private premiums $(-0.19$ versus -0.24$)$ combined with increasingly regressive out-of-pocket payments $(-0.47$ versus -0.39$)$. (Note 20$)$ However, the composition of financing has changed substantially since 1987 . The share of total financing that is public has grown from 49 to 58 percent between 1987 and 2004 and this alone could decrease regressivity. Within the private sector, we show a marked decline in the share of funding that is out-of-pocket, a trend which would also reduce overall regressivity.

\subsection{State Specific Results}

Table 4 provides aggregated equity analysis for California and New York to measures generated from aggregated data for Florida and Texas. On a practical level, the sample size for these states makes analysis at the sub-national level reliable. More importantly, these four states represent very different tax structures. Florida and Texas have no personal income tax and the Institute on Taxation and Economic Policy (ITEP) identifies these two states as among the states with the most regressive tax systems (Davis, et al., 2009). On the other hand, both New York and California have a progressive income tax and New York is identified by ITEP as among the four least regressive states in the country. These states also differ in terms of the level of their public sector spending on health care for low income populations with New York being the highest Medicaid spender. The results in Table 4 demonstrate that the lack of personal income taxes in FL and TX result in a highly regressive state/local incidence compared to a slightly progressive pattern in CA and NY. However, when combined with the progressive federal financing in all four states and the smaller state/local share of financing in FL and TX, the overall pattern for public spending is similarly progressive among families residing in these four states. The incidence of private sector spending is also similar in CA/NY (-.24) to that in FL/TX $(-.21)$ but the lower share of private sector financing in CA/NY, 37\% versus $46 \%$ in $\mathrm{FL} / \mathrm{TX}$, helps contribute to an overall proportional distribution of the financing of health spending among residents of California and New York compared to the more regressive distribution found in Texas and Florida. 
Table 4. Differences by state

Progressivity of Health Care Financing

\begin{tabular}{|c|c|c|c|c|c|c|c|c|}
\hline & $\begin{array}{c}\text { Gini } \\
\text { Coefficient }\end{array}$ & Federal & $\begin{array}{l}\text { State/ } \\
\text { Local }\end{array}$ & $\begin{array}{c}\text { Total } \\
\text { Public }\end{array}$ & Premiums & OOP & $\begin{array}{c}\text { Total } \\
\text { Private }\end{array}$ & $\begin{array}{c}\text { All } \\
\text { Sources }\end{array}$ \\
\hline California and New York & 0.48 & & & & & & & \\
\hline Shares & & $44 \%$ & $19 \%$ & $63 \%$ & $25 \%$ & $12 \%$ & $37 \%$ & \\
\hline Kakwani & & 0.18 & 0.03 & 0.14 & -0.15 & -0.41 & -0.24 & -0.0001 \\
\hline $\begin{array}{l}\text { Per Family Spending in the } \\
\text { Quintile }\end{array}$ & Bottom & $\$ 456$ & $\$ 581$ & $\$ 1,037$ & $\$ 798$ & $\$ 1,265$ & $\$ 2,063$ & $\$ 3,100$ \\
\hline Florida and Texas & 0.46 & & & & & & & \\
\hline Shares & & $46 \%$ & $9 \%$ & $54 \%$ & $30 \%$ & $16 \%$ & $46 \%$ & \\
\hline Kakwani & & 0.19 & -0.15 & 0.14 & -0.11 & -0.39 & -0.21 & -0.021 \\
\hline $\begin{array}{l}\text { Per Family Spending in the } \\
\text { Quintile }\end{array}$ & Bottom & $\$ 458$ & $\$ 402$ & $\$ 860$ & $\$ 758$ & $\$ 1,387$ & $\$ 2,145$ & $\$ 3,005$ \\
\hline
\end{tabular}

\subsection{Tax Expenditure}

There is a long standing debate in the literature regarding the progressivity versus regressivity of the tax treatment of health insurance, focusing largely on the benefit of the tax expenditure and whether that benefit is measured in absolute dollars or as a share of income (Gruber, 2009; Himmelstein \& Woolhandler, 2009; Selden \& Moeller, 2000). In our model, we incorporate the reduction in premiums and the implicit increase in tax burden borne by all tax payers to estimate the redistributive implications of the subsidy. Table 5 shows estimates of progressivity for each component of spending before and after consideration of the tax expenditure. The tax treatment for health insurance effectively shifts 12 percent of total spending from the private to the public sector, allocated proportionally to federal and state spending. This has two different effects on progressivity. On the one hand, the benefit of the tax subsidy accrues proportionally with income, reducing the premium burden to a greater degree as income increases. Therefore, the Kakwani measure of progressivity for premiums declines from -0.07 (measured on a pre-tax basis) to -0.12 after taxes. On the other hand, the shift of financing to the public sector increases the share of health care spending financed by progressive funding sources (federal) from 33 to 44 percent of all health care spending. In the aggregate, then, the tax treatment of health insurance results in a system that is marginally less regressive.

Table 5. Implications of the tax expenditure

\begin{tabular}{lccccccc}
\hline & Federal & $\begin{array}{c}\text { State/ } \\
\text { Local }\end{array}$ & $\begin{array}{c}\text { Total } \\
\text { Public }\end{array}$ & Premiums & OOP & $\begin{array}{c}\text { Total } \\
\text { Private }\end{array}$ & $\begin{array}{c}\text { All } \\
\text { Sources }\end{array}$ \\
\hline Before Tax Expenditure for Health Insurance & & & & & & \\
Share of Total Spending & $33 \%$ & $12 \%$ & $45 \%$ & $40 \%$ & $14 \%$ & $55 \%$ & \\
Kakwani Measure of Progressivity & 0.20 & -0.01 & 0.15 & -0.07 & -0.40 & -0.16 & -0.02 \\
& & & & & & & \\
After Tax Expenditure for Health Insurance & & & & & & \\
Shares of Total Spending & $44 \%$ & $14 \%$ & $58 \%$ & $28 \%$ & $14 \%$ & $42 \%$ & \\
Kakwani Measure of Progressivity & 0.20 & 0.00 & 0.15 & -0.12 & -0.40 & -0.21 & -0.01
\end{tabular}

\section{Discussion and Conclusion}

We find that the US health care system is generally regressively financed such that lower income families spend a larger share of income for health care than do higher income families. The overall patterns suggest that only federally financed health care spending is progressively financed, while health care financed through state and local sources, premiums, and out-of-pocket spending are distributed regressively throughout the population. 
When compared with the Wagstaff et al. study, however, we find evidence that the US system has become slightly less regressive over time, largely due to an increasing share of spending by the federal public sector. This pattern is in contrast to an increasing concentration of income in the highest income quintile over the last two decades in the US (http://www.cbo.gov/publication/42537). There are broad trends in health care spending and direct tax policy changes that may have affected this change in health care financing. With respect to health care spending, large changes have resulted from: 1) increased numbers and share of the population who lack any source of coverage; 2) increased Medicaid covered populations and services due to mandated as well as voluntary state expansions; 3 ) increased Medicare covered populations due largely to aging of the population; and 4) medical care inflation in excess of wage increases. With respect to tax policy, we further note changes such as 5) removal of the limit on the tax base used to finance Medicare Part A; 6) decreased number of tax brackets and marginal rates from the 1980's to 2004; and 7) a marked increase in the earned income tax credit. The first three developments are clearly consistent with a secular increase in the percent of our health care financing system that is publicly financed. Increased inflation also increases the public dollars needed for direct programs as well as the public subsidy of private insurance. Since the overall public sector in the US has historically been two-thirds federal, we would expect this growth, a-priori, to reduce the regressivity of the total financing system. In addition, the federal/state shared financing of Medicaid with higher matching rates for lower income states and increased matching during the 2003-2004 recession likely plays a role in reducing overall regressivity. The increased number of uninsured and the Medicaid expansions within the lowest income bracket could mean lower premium payments for families in this bracket compared to 1987, while higher costs of medical care and more uninsured could relate to the increase in the regressivity of out-of-pocket payments despite the marked decline in the share of total revenue they comprise. Out-of-pocket spending as a source of funding declined from 22 to 12 percent of the total between 1987 and 2004 in the respective analyses, consistent with NHEA estimates.

The structure of state tax systems combined with the aggregate spending decisions made at the state level affect the overall equity of the health care financing system. This implies that the impacts of reform on the overall equity of the system could vary by state; this is exacerbated by the US Supreme Court decision which will allow states to refuse federal funding for Medicaid expansion. The findings at the state level highlight that the Kakwani index measure of equity is not the same as measuring the overall burden of the system. We note that in the aggregate, the lowest quintile of the population in California and New York still bear a greater absolute financial burden since aggregate spending financed by the lowest income group is higher than in Florida and Texas. However, this difference is small and if even the low-income in California and New York have a greater demand for public goods than similar income households in Florida and Texas, this may be an efficient allocation of resources. However, the financing system distributes these higher levels of spending more equitably with respect to income in these two former states compared with Florida and Texas.

This study generates a significant number of additional questions. With respect to our estimate of the implications of the tax subsidy on incidence, we note that both the level and the distribution of gross and net premiums depend upon a clear understanding of the nature of risk pooling within the employer market. Evidence regarding the potential for risk pooling to be incomplete implies the need to test the sensitivity of our incidence estimates to an alternate distribution of premiums within the labor market. Additionally, our assumption that all public spending is financed from current revenue sources ignores the potential for intergenerational wealth transfers as part of the financing structure. These suggest future research questions that should be addressed.

A more complete picture of the equity of the overall health care system would consider both the financing and the benefits of the spending. As argued earlier, this approach also has limitations and this paper focuses solely on equity of the financing system for care, leaving aside the distribution of the benefits of care. From a theoretical perspective, estimates of net equity including the benefits of health spending would need to incorporate the differential marginal utility of health care consumption and insurance as they vary with income. As noted, this approach is beyond the scope of the present study. (Note 21)

Understanding who pays for health care is an important component of assessing the performance of the system as it currently exists. This study attempts to fill the historical gap in the literature that has not assessed vertical equity in the financing of the US system for almost two decades. In light of the significant public expansion of coverage, escalating private premiums but declining levels of private coverage and changing out-of-pocket spending, it is important to assess the overall incidence in a more current period. This will be particularly important as a benchmark for assessment as the US system embarks on a period of reform and one which might result in even more state variation with respect to overall levels of spending as well as federal/state sharing of public financing. We have documented our methods and our incidence assumptions for ease of comparison in future analyses. 
The Patient Protection and Affordable Care Act (PPACA) of 2010 includes provisions designed to improve access to quality, affordable health care for all Americans. PPACA should, through expansion of coverage, decrease out-of-pocket spending for health care among uninsured populations. It will increase public spending on health care, and in particular, federal spending by providing new subsidies for private health insurance targeted at low to moderate income families as well as higher federal sharing of the mandated Medicaid expansions. There are new taxes on medical devises, pharmaceuticals, and insurance products in the law as well as increases in the rate and base for the health care portion of the payroll tax. The final incidence of the new taxes, the subsidies for private premiums and out-of-pocket spending, and the changes in coverage levels created through the PPACA will require careful analysis for future incidence studies.

\section{Acknowledgements}

This research was funded by the Robert Wood Johnson Foundation's Changes in Health Care Financing and Organization (HCFO) Program. The authors thank the HCFO staff for their financial and conceptual support of the project. They are also grateful for valuable comments and suggestions from Thomas Selden at AHRQ, John Holahan and Bowen Garrett at the Urban Institute, William Custer and David Sjoquist at Georgia State University, Zhou Zhang at Emory University, Lynn Blewitt at SHADAC, and Howard Chernick at Hunter College, CUNY.

\section{References}

Aronson, J.R., Johnson, P., \& Lambert, P.J. (1994). Redistributive Effect and Unequal Income Tax Treatment. The Economic Journal, 104(423), 262-270. http://dx.doi.org/10.2307/2234747

Bahl, R., Martinez-Vazquez, J., \& Wallace, S. (2002). State and Local Government Choices in Fiscal Redistribution. National Tax Journal, 55(4), 723-742.

Besley, T.J., \& Rosen, H.S. (1999). Sales Taxes and Prices: An Empirical Analysis. National Tax Journal, 52(2), 0157-0178.

Bhattacharya, J., \& Bundorf, M.K. (2009). The incidence of the healthcare costs of obesity. Journal of Health Economics, 28(3), 649-658. http://dx.doi.org/10.1016/j.jhealeco.2009.02.009

Bhattacharya, J., \& Lakdawalla, D. (2006). Does Medicare benefit the poor? Journal of Public Economics, 90(1-2), 277-292. http://dx.doi.org/10.1016/j.jpubeco.2005.01.001

Burkhauser, R., Feng, S., \& Jenkins, S.P. (2009). Using the P90/P10 Index to Measure US Inequality Trends with Current Population Survey Data: A View from the US Census Bureau Vaults. The Review of Income and Wealth, 55(1), 166-185. http://dx.doi.org/10.1111/j.1475-4991.2008.00305.x

Cantor, J.C. (1988). The Burden of Financing Health Care in the United States. Unpublished Dissertation, Johns Hopkins University, Baltimore.

Centers for Medicare \& Medicaid Services. National Health Expenditure Data | Historical. Retrieved January 10, 2010 , from http://www.cms.hhs.gov/NationalHealthExpendData/02_NationalHealthAccountsHistorical.asp\#TopOfPage

Centers for Medicare \& Medicaid Services. (2010). National Health Expenditure Data | Projected. Retrieved January 10, 2010, from http://www.cms.hhs.gov/NationalHealthExpendData/03_NationalHealthAccountsProjected.asp\#TopOfPage

Congressional Budget Office. (2010). The Long-Term Outlook for Health Care Spending. Retrieved January 20, 2010, from http://www.cbo.gov/ftpdocs/87xx/doc8758/MainText.3.1.shtml

Cronin, J.A. (1999). Public Finance in Theory and Practice. Washington, DC: Office of Tax Analysis, US Department of Treasury. Retrieved from http://www.treasury.gov/resource-center/tax-policy/tax-analysis/Documents/ota85.pdf

Davis, C., Davis, K., Gardner, M., McIntyre, R.S., MacLynch, J., \& Sapozhnikova, A. (2009). Who Pays? A Distributional Analysis of the Tax Systems in all 50 States (3rd ed.).

Deb, P., Manning, W., \& Norton, E. (2008). Modeling Health Care Costs and Counts. [Presentation, ASHE Duke University Conference].

Emanuel, E.J., \& Fuchs, V.R. (2008). Who Really Pays for Health Care? JAMA, 299(9), 1057-1059. http://dx.doi.org/10.1001/jama.299.9.1057 
Feenberg, D.R., Mitrusi, A., \& Poterba, J.M. (1997). Distributional Effects of Adopting a National Retail Sales Tax. Tax Policy and the Economy, 11, 49-89.

Gottschalk, P., Wolfe, B., \& Haveman, R. (1989). Health care financing in the US, UK and The Netherlands: Distributional consequences. In A. Chiancone \& K. Messere (Eds.), Changes in revenue structures. Detroit: Wayne State University Press.

Gruber, J. (1994). State-mandated benefits and employer-provided health insurance. Journal of Public Economics, 55(3), 433-464. http://dx.doi.org/10.1016/0047-2727(93)01407-2

Gruber, J. (2009). A Win-Win Approach to Financing Health Care Reform. NEJM, 361(1), 4. http://dx.doi.org/10.1056/NEJMp0904855

Harberger, A.C. (1962). The Incidence of the Corporate Income Tax. The Journal of Political Economy, 70(3), 215-240. http://dx.doi.org/10.1086/258636

Himmelstein, D., \& Woolhandler, S. (2009). The regressivity of taxing employer-paid health insurance. The New England Journal of Medicine, 361(10), e101. http://dx.doi.org/10.1056/NEJMopv0907478

Jensen, G.A., \& Morrisey, M.A. (2001). Endogenous Fringe Benefits, Compensating Wage Differentials and Older Workers. International Journal of Health Care Finance and Economics, 1(3/4), 203-226. http://dx.doi.org/10.1023/A:1013711501104

Keehan, S.P., Sisko, A.M., Truffer, C.J., Poisal, J.A., Cuckler, G.A., Madison, A.J., et al. (2011). National Health Spending Projections Through 2020: Economic Recovery And Reform Drive Faster Spending Growth. Health Affairs, 30(8), 1-12. http://dx.doi.org/10.1377/hlthaff.2011.0662

Ketsche, P., Adams, E.K., Wallace, S., Kannan, V., \& Kannan, H. (2011). Lower Income Families Pay a Higher Share of Income Toward National Health Spending Than Higher Income Families Do. Health Affairs, 30(9), 1637-1646. http://dx.doi.org/10.1377/hlthaff.2010.0712

Kotlikoff, L.J., \& Summers, L.H. (1979). Tax Incidence in a Life Cycle Model with Variable Labor Supply. The Quarterly Journal of Economics, 93(4), 705-718.

Leibowitz, A. (1983). Fringe Benefits in Employee Compensation. Unpublished manuscript. Retrieved from http://www.nber.org/chapters/c7385.pdf

McClellan, M., \& Skinner, J. (2006). The Incidence of Medicare. Journal of Public Economics, 90(1-2), 257-276. http://dx.doi.org/10.1016/j.jpubeco.2005.05.008

Miller, R.D. (2004). Estimating Compensating Differentials for Employer Provided Health Insurance Benefits. International Journal of Health Care Finance and Economics, 4, 27-31. http://dx.doi.org/10.1023/B:IHFE.0000019259.74756.65

Morlock, R. (2000). Compensating Wage Differentials in the Presence of Employer Provided Health Insurance. Wayne State University.

Olson, C. (2002). Do Workers Accept Lower Wages in Exchange for Health Benefits? Journal of Labor Economics, 20(2), S91-S114. http://dx.doi.org/10.1086/338675

Ozkan, S. (2011). Income Differences and Health Care Expenditures over the Life Cycle. Unpublished manuscript, Philadelphia.

Pauly, M.V. (1997). Health Benefits at Work: An Economic and Political Analysis of Employment-Based Health Insurance. Ann Arbor: University of Michigan Press.

Poterba, J.M. (1996). Retail price reactions to changes in state and local sales taxes. National Tax Journal, 49(2), $165-176$.

Quincy, L. (2008). Using Section 125 Premium- Only Plans to Expand Health Coverage (Vol. \#5): Mathematica Policy Research Institute.

Ring, R.J. (1999). Consumers' Share and Producers' Share of the General Sales Tax. National Tax Journal, 52(1), 79-90.

Royalty, A.B., \& Solomon, N. (1999). Health Plan Choice: Price Elasticitieis in a Managed Competition Setting. The Journal of Human Resources, 34(1), 1-41. http://dx.doi.org/10.2307/146301 
Scheiner, L. (1999). Health Care Costs, Wages, and Aging. Unpublished manuscript, Washington, DC. http://dx.doi.org/10.2139/ssrn.165530

Selden, T.M., \& Bernard, D.M. (2004). Tax Incidence and Net Benefits in the Market for Employment-Related Health Insurance. International Journal of Health Care Finance and Economics, 4(2), 167-192. http://dx.doi.org/10.1023/B:IHFE.0000032422.90886.86

Selden, T.M., \& Moeller, J.F. (2000). Estimates of the Tax Subsidy for Employment Related Health Insurance. National Tax Journal, 53(4).

Selden, T.M., \& Sing, M. (2008). The Distribution Of Public Spending For Health Care In The United States, 2002. Health Affairs, 27(5), w349-w359. http://dx.doi.org/10.1377/hlthaff.27.5.w349

Shiels, J., \& Haught, R. (2004). The Cost of Tax Exempt Health Benefits in 2004. Health Affairs, W-4, 106-112. http://dx.doi.org/10.1377/hlthaff.w4.106

Skinner, J., \& Zhou, W. (2004). The Measurement and Evolution of Health Inequality: Evidence from the U.S. Medicare Population National Bureau of Economic Research.

Smeeding, T.M., \& Weinberg, D.H. (2001). Toward A Uniform Definition Of Household Income. Review of Income and Wealth, 47(1), 1-24. http://dx.doi.org/10.1111/1475-4991.00001

Smith, S., \& Normand, C. (2009). Analysing equity in health care financing: A flow of funds approach. Social Science and Medicine, 69, 379-386. http://dx.doi.org/10.1016/j.socscimed.2009.05.030

Sommers, B.D. (2005). Who Really Pays for Health Insurance? The Incidence of Employer-Provided Health Insurance with Sticky Nominal Wages. International Journal of Health Care Finance and Economics, 5(1), 89-118. http://dx.doi.org/10.1007/s10754-005-6603-5

Wagstaff, A., \& Doorslaer, E.v. (1992). Equity in the finance of health care: Some international comparisons. Journal of Health Economics, 11(4), 361-387. http://dx.doi.org/10.1016/0167-6296(92)90012-P

Wagstaff, A., Doorslaer, E.v., Burg, H.v.d., Calonge, S., Christiansen, T., Citoni, G., et al. (1999). Equity in the finance of health care: some further international comparisons. Journal of Health Economics, 18(3), 263-290. http://dx.doi.org/10.1016/S0167-6296(98)00044-7

\section{Notes}

Note 1 . We test the sensitivity of our results to a more narrow income definition (cash) and find the fundamental results are unchanged. Results expressed with respect to cash income are provided for comparison with historical research.

Note 2. Income components: Wages \& Salaries; Farm income; Self-employment income; Retirement income; Disability income; Social Security income; Supplemental Security income; Tax credits; Child support; Alimony; Capital gains; Interest; Dividends; Rent income; Public assistance; Financial assistance; Energy assistance; Education assistance; Family market value of food stamps, school lunch, Medicare, Medicaid, and housing subsidy; Unemployment compensation; Worker's compensation; Veteran's pay; Survivor's pay; Employer FICA payments; Employer contribution to health insurance and retirement; Imputed rent for owner-occupied dwellings

Note 3. One alternative used with top coding is to use the $10^{\text {th }}$ and $90^{\text {th }}$ percentile cell means (P10/ P90) but this would not permit comparison with historical studies, would be inappropriate for calculating the Kakwani index, and is potentially subject to bias (Burkhauser, Feng, \& Jenkins, 2009) .

Note 4. We tested the sensitivity of our analysis to this decision by constructing household units and found no significant changes in the overall results. Further, if our goal were to estimate burden over a lifetime, then an individual rather than family level analysis would be more appropriate because of the mobility across social strata of individuals within families. However, we view our results as providing a point-in-time estimate of the equity of the system.

Note 5 . We use the equivalence scale: $(\mathrm{A}+0.5 \mathrm{~K})^{0.5}$, where $\mathrm{K}$ represents children under 15 years and $\mathrm{A}$ represents all other members of the family (Aronson, Johnson, \& Lambert, 1994; Wagstaff, et al., 1999) to adjust for lower use of resources by children and economies of scale from family size. Without this adjustment, we would implicitly endorse the notion that families of equal income are equally 'well-off' regardless of size and composition, thereby impacting estimates of equity. 
Note 6. The general fund here is constructed to include non ear-marked taxes. We omit payroll taxes at the federal level, fuel taxes at the federal and state levels and the portion of property taxes earmarked for public education at the local level.

Note 7. Note that states and localities vary extensively not only with respect to the tax rates imposed but also with respect to the type of taxes imposed.

Note 8. See for example CBO (1996).

Note 9. IRS reports that approximately 11.5 percent of corporate assets of domestic firms are held by foreigners. We implicitly assume that the net US tax liability of such companies is in proportion to their US based operations.

Note 10. Rents and imputed rents of owner occupied housing are used as proxies for housing consumption.

Note 11. (AK, LA, MT, NM, ND, OK, TX, WV, and WY).

Note 12. Since coal is used an intermediate product for a variety of products, the tax on coal can be effectively passed on to consumers at large.

Note 13. In 2004, payroll taxes funded 93 percent of Medicare Part A. The remaining 7 percent was funded from the federal general revenue and hence, 73 percent of this 7 percent of Part A was allocated to the Individual Income Tax at the federal level.

Note 14. This portion of the research in this paper was conducted at the CFACT Data Center and the support of the Agency for Healthcare Research and Quality (AHRQ) is acknowledged. The results and conclusions of this paper are those of the authors and do not indicate concurrence by AHRQ or the Department of Health and Human Services.

Note 15. Shiels and Haught (2004) estimate the tax expenditure associated with deductions for out-of-pocket spending to be 7.4 billion. At least a significant portion of this is likely associated with high out-of-pocket spending among institutionalized populations. Our treatment of tax expenditures is redistributive, so ignoring this particular tax expenditure can result in a slight misallocation of $0.4 \%$ of all expenditures.

Note 16. NHEA estimates suggest that consumer payments for nursing home care comprise almost 17 percent of all direct consumer spending for health care services in 2004. These consumers also incur out-of-pocket spending for other services while institutionalized.

Note 17. Although there are individuals who fail to enroll in Medicare Part B, this is not observable and the model does not control for differences in the likelihood of take up in Part B that are associated with family income. Additionally, a small number of individuals pay significant premiums for Part A coverage; regrettably this is also ignored in our incidence model as we have no internal or external data sources for making this imputation.

Note 18. This may be counterintuitive but is easily explained by our use of a broad income measure. Lower income families have a higher share of income in non-cash form and thus not subject to payroll taxes.

Note 19. We note that our incidence assumptions differ from some of those in the prior analysis. The prior study assumes corporate income taxes fall only on shareholders which would result in a more progressive pattern than the split between capital and labor income used here. On the other hand, they assume that property taxes fall on property owners thereby omitting the potential shifting of these taxes to renters and hence, omit a source of regressivity that we incorporate. Another key difference is that we distribute the incidence of the tax expenditure for private insurance across payroll and all federal, state (those with an income tax) general fund taxes while Wagstaff et al places this burden entirely on the federal income tax. Overall, this would make their tax expenditure incidence more progressive. Furthermore, our focus on federal vs. state and local taxing bodies differs from the prior study's focus on direct vs. indirect taxation. Thus we present only the aggregate public financing numbers.

Note 20. We note that we have included the highly regressively distributed estimates for out-of-pocket spending from institutionalized populations in our model, but this appears to be missing from the prior study.

Note 21. As a practical matter, the data sets that provide the best estimates of heath care services obtained (MEPS data) in order to identify the distribution of benefits are severely limiting with respect to our ability to estimate the burden with respect to state spending, a large focus of this paper. 


\section{Appendices}

Appendix 1. Sources Utilized for Healthcare Expenditure Data

\section{Source}

Used For

\section{Publicly Funded Healthcare Expenditures}

Federal

Medicare Trust Fund Report

Centers for Medicare \& Medicaid Service's Medicaid

Financial Management Report

National Health Expenditure Accounts

State

Centers for Medicare \& Medicaid Service’s Medicaid

Financial Management Report

National Association of State Budget Officers' 2002-2003

State Health Expenditure Report

National Academy for Social Insurance

State and Local

CPS data on the uninsured and Published data on Tax funded uncompensated care $^{\mathrm{a}}$

National Association of County and City Health Officials

National Profile of Local Health Departments
Medicare Parts A and B

Medicaid and CHIP: Federal Share

Department of Defense

Maternal/Child Health

Veterans' Administration

Vocational Rehabilitation

Gen Hosp/Med NEC

ADAMHA/SAMHSA

Indian Health Services

Federal Worker's Compensation

Medicaid and Chip: State Share

State Insurance \& Access Expansion

Community Based Services

Direct Public Health Care

Higher Education Health

Corrections

State Facility Based Services

Worker's Compensation

Uncompensated Care

Health Department Direct Services

\section{Out-of-Pocket}

Medical Expenditure Panel Survey's Household Component

Medicare Current Beneficiary Survey

Premiums

Employer Sponsored Insurance

Medical Expenditure Panel Survey's Insurance Component

National Council of State Legislators

Kaiser Health Research and Educational Trust

Non Group Health Insurance

America's Health Insurance Plans

Government Accountability Office
Non-Institutionalized Out-of-Pocket spending Institutionalized Out-of-Pocket spending

Mean total premium and employer and employee share: Adjusted for state, firm size, industry, and tier

Mean premiums and employer and employee share by state

Average cost for retiree health for the 65+ population (adjusted by the ratio of state to national average for all ESI

Mean premiums for individual and families by state and age bands

Mean premiums for Medigap Plan F by state 
Source

Used For

Public Insurance

Medicare Trust Fund Report

State Reports

Medicare Parts A and B enrollment

Medicaid/CHIP premiums

\begin{abstract}
${ }^{\mathrm{a}} \mathrm{J}$. Hadley and J. Holahan, The Cost of Care for the Uninsured: What do We Spend, Who Pays, and What Would full Coverage Add to Medical Spending, KFF Issue Update, 2004
\end{abstract}

Appendix 2. Summary of Tax Incidence Theory

Individual Income Tax

Workers allocate their time between labor and leisure. An income tax reduces a worker's net wage and therefore reduces the relative price of leisure; the lower opportunity cost of leisure induces workers to substitute leisure for work. However, there is also an income effect from the tax induced decline in wages which leads to an increase in work effort. ${ }^{[1]}$ According to most studies, the elasticity of total labor supply with respect to income tax is typically small, ${ }^{[2]}$ although some sub-groups respond differently (Eissa \& Liebman, 1996; Hausman \& Poterba, 1987). Thus, since wages dominate income and empirical work generally confirms an inelastic supply of labor, there is some consensus that the incidence of individual income tax falls entirely on labor and that assumption is used here.

Payroll Tax

Although the statutory incidence of payroll tax in the U.S. is equally borne by employees and employers, employees are assumed to bear the full economic burden of this tax. This is also attributed to the conclusions that labor supply elasticities with respect to income taxes are small and therefore the employer share of the tax can be passed on to the employees (Brittain, 1971) 1971). This conclusion has been verified by other studies and Gruber (1997) argues it holds even in the presence of an upward sloping supply curve. Thus, we use the assumption that employees bear the full burden of payroll taxes.

\title{
Sales \& Excise Taxes
}

The economic burden of sales and excise taxes are assumed to fall on consumers of the taxed good. While Poterba (1996) concludes that state and local taxes are fully shifted to consumers in the form of higher prices, Besley and Rosen (1999) use extensive price data for disaggregated goods and conclude that the price responses varied by products. However, shifting was at least equal to the tax. Given scant research on tax shifting in non-competitive markets and the commonly found result of one-for-one shifting, incidence studies continue to rely on the assumption of only full shifting. In this study, we distinguish between consumer and producer paid sales taxes ${ }^{[3]}$ as well as sales taxes exported through tourism. ${ }^{[4]}$ The assumption that the taxes are ultimately shifted to consumers is maintained in case of all three 'portions' of these taxes. ${ }^{[5]}$

Corporate Taxes

There is almost unanimous agreement regarding the incidence of individual income, payroll taxes, and sales taxes, ${ }^{[6]}$ but the question of who bears the burden of corporate taxes is controversial. Since corporations are allowed to deduct interest paid on debt to derive taxable income, the corporate tax is generally viewed as a tax on returns to equity capital. ${ }^{[7]}$ Though the tax is levied on capital in the corporate sector, the literature argues that the economic incidence falls on capital in all sectors as capital in the corporate sector migrates into the non-corporate sector until tax returns are equalized across both sectors (Harberger, 1962). Returns to labor are also affected due to the migration of capital and the resulting drop in productivity. ${ }^{[8]}$ However, the proportion in which the economic burden is borne by capital and labor depends on the elasticities of substitution between the factors of production and elasticities of consumer demand in the different sectors. This conclusion can also be extended to the case of an open economy with mobile capital as shown by Randolph (2006) and Gravelle and Smetters (2006), which leads to an even greater effect on labor as capital flees internationally. In this study we present results using the incidence assumption that labor and capital bear the burden of corporate tax equally. We also allow for the possibility of shifting to foreign owned capital and thereby assume that 11.5 percent ${ }^{[9]}$ of the capital burden of corporate tax is exported outside the US economy.

Property Taxes

The economic burden of property taxes is assumed to fall on capital and consumers of housing services but there is some debate about the relative shares. ${ }^{[10]}$ Mieszkowski (1972) reconciled opposing views on the incidence of property tax by arguing that the property tax can be decomposed into an average national tax rate and a differential local rate. 
Though the average tax is levied on housing capital, following Harberger's analysis, the economic incidence of this tax is borne by all capital. ${ }^{[11]}$ In the presence of perfect capital mobility but imperfect labor and consumer mobility, the migration of capital from high tax to lower tax localities causes the incidence of the differential rate to fall on labor and consumers of housing ${ }^{[12]}$ As other incidence analyses have done, we combine these theoretical approaches and assume the burden of the property tax is shared equally between capital and consumers of housing (owners and renters).

\section{Severance Taxes}

Severance taxes on oil, gas and coal are used only in a small number of states (AK, LA, MT, NM, ND, OK, TX, WV, and WY,). The severance tax on oil/gas is assumed to be borne by owners of capital as it reduces the rate of return for mineral owners (Ranck, 1985) and largely hits domestic owners and sellers given the global and competitive nature of the market (McLure, 1978). Extending the analysis to a general equilibrium framework following Harberger (1962), the severance tax on oil is passed on to owners of all capital. However, the severance tax on coal is assumed to be borne by all consumers nationally. This results from the dominance of a few states in this market and the lack of international competition, which implies that these taxes can be passed on to all consumers.[13]

\section{Estate Taxes}

Gale and Slemrod (2001) state that there are two main views on who bears the estate tax burden, the donors and the descendants. Given its relatively low revenue generation, the estate tax is seen as an instrument to redistribute wealth in society (Musgrave \& Musgrave, 1989). Here, we assume that the economic burden of the estate tax is borne by the descendants, an assumption adopted by many incidence studies (Cronin, 1999; Feenberg, Mitrusi, \& Poterba, 1997).

[1] Leisure is assumed to be a normal good, i.e. its consumption is directly related to income.

[2] See Hausman (1983) for a thorough analysis of the theoretical and econometric arguments regarding income tax and labor supply; Hausman's estimated elasticity of labor supply is typically larger than those found in other studies. Treist (1990) uses a methodology similar to Hausman and concludes that the elasticity of labor supply of married men is smaller while the results are similar for married women. Larger elasticities found for married women is due to non-participants entering the workforce implying that elasticies for those already participating are small.

[3] We use the state specific breakdown of sales taxes paid by consumers and producers provided by Ring (1999).

[4] For the consumer component of the sales tax, the estimates for amount of exported to tourists by each state are calculated on the basis of the state's share of domestic and international travel visits/expenditures as published in the Statistical Abstract, tables 1237 and 1239. The business portion of the sales tax that is exported outside of the country is estimated based on estimates from the Internal Revenue Service (IRS) of the percent of corporate assets held by foreigners.

[5] The burden of non-exported sales tax on business is assumed to fall on consumers within the state while the burden of exported taxes is assumed to fall on all consumers nationally. The burden of taxes exported through tourism is also assumed to be borne by consumers nationally in proportion to personal income. See Table $\mathrm{X}$ for a full summary.

[6] This holds under the assumption of competitive markets but the incidence of taxes in the context of imperfectly competitive markets is more open to debate; see Fullerton and Metcalf (2002) for a brief overview.

[7] See for example CBO (1996)

[8] The factor substitution effect is to reduce the relative price of capital as producers shift away from the relatively costlier capital (relative price on capital in this sector rises due to the tax) to labor. Consumers on the other hand may substitute relatively cheaper non-corporate goods for corporate goods, if the corporate sector is more labor intensive than the non-corporate sector, the resulting drop in the demand of labor due to reduction in output depresses the relative price of labor; effectively, passing on the incidence of the corporate tax to labor.

[9] IRS reports that approximately 11.5 percent of corporate assets of domestic firms are held by foreigners. We implicitly assume that the net US tax liability of such companies is in proportion to their US based operations.

[10] Rents and imputed rents of owner occupied housing are used as proxies for housing consumption.

[11] This analysis assumes that savings is unaffected by taxes on capital.

[12] See (Zodrow, 2008) for an updated exposition of the different views. Empirical analysis by Carroll and Yinger (1994) partially confirm the predictions set out by Meiszkowski.

[13] Since coal is used an intermediate product for a variety of products, the tax on coal can be effectively passed on the consumers at large. 
Appendix 3. Tax Bases for the various taxes

\begin{tabular}{|c|c|c|c|}
\hline \multirow[t]{3}{*}{ Tax Type } & \multicolumn{3}{|c|}{ Tax Base } \\
\hline & \multicolumn{3}{|c|}{ Government Level } \\
\hline & Federal & State \& Local & \\
\hline Individual Income Tax & Income & Income & \\
\hline Corporate Income Tax ${ }^{\mathrm{e}}$ & Wages $^{\mathrm{a}}$, Capital $^{\mathrm{b}}$ & Wages $^{\mathrm{a}}$, Capital $^{\mathrm{b}}$ & \\
\hline Federal Payroll Tax & Wages $^{a}$ & & \\
\hline General Sales Tax ${ }^{f}$ & & $\begin{array}{l}\text { Item specific Consumption, } \\
\text { Expenditures, Personal Income }\end{array}$ & Total \\
\hline Excise $\operatorname{Tax}^{\mathrm{g}}$ & $\begin{array}{l}\text { Item specific Consumption, Total } \\
\text { Expenditures }\end{array}$ & Total Expenditures & \\
\hline Severance Tax (coal, oil) ${ }^{\mathrm{h}}$ & & Total Expenditures, Capital ${ }^{\mathrm{b}}$ & \\
\hline Property Tax ${ }^{\mathrm{i}}$ & & Housing Consumption ${ }^{\mathrm{d}}$, Capital ${ }^{\mathrm{b}}$ & \\
\hline License Fees ${ }^{j}$ & & Item specific Consumption & \\
\hline Other Taxes ${ }^{\mathrm{k}}$ & Adults & Adults & \\
\hline
\end{tabular}

Notes:

a Wages includes wages and salary, self-employment income, and farm income.

b Capital includes interest, dividends, net capital gains, and rent income; and is always distributed nationally whether as part of the federal or state tax base.

c Personal Income is the sum of Wages and Capital.

d Housing Consumption equals rent paid or imputed rent for owner occupied dwellings.

e Corporate income tax falls on wage and capital income with the ratio 50:50. The half that falls on capital is reduced by $11.5 \%$ to account for international associated with mobile capital and is distributed nationally (as mentioned in note $b$ ).

f Total expenditures serve as the tax base for general sales tax revenue generated from business and distributed by state for businesses within the state and distributed nationally for businesses in other states within the nation. Sales taxes paid serve as the tax base for general sales tax revenue generated from consumers within the state. Personal income serves as the tax base for general sales tax revenue generated from consumers in other states within the nation and is distributed nationally. The proportion of general sales tax revenue generated from international businesses or consumers are omitted from the model.

$\mathrm{g}$ At the federal level, alcohol and tobacco excise taxes are based on the family's consumption of those items; whereas all other excise taxes are based on overall consumption. At the state level, all taxes on the sale of selective items are based on share of consumption of those items.

$\mathrm{h}$ For coal, severance tax is based on total consumption distributed nationally. For oil, severance tax is based on capital distributed nationally (as mentioned in note b).

i Property tax falls on housing consumption and capital income with the ratio 50:50. The half that falls on capital is reduced by $11.5 \%$ to account for international exportation and is distributed nationally (as mentioned in note b).

j Licenses include Tobacco, Motor Vehicle, and Corporate licenses which are based on tobacco consumption, car $\&$ truck consumption, and capital distributed nationally (as mentioned in note b). All other licenses are based on the number of adults in the family.

$\mathrm{k} \quad$ All 'other' federal and state taxes were distributed to families based on their share of all adult family members. 